\title{
Canadian Women Poets and the Syndrome of the Female Man
}

\author{
A Note on the Poetry of Audrey \\ Alexandra Brown and Anne \\ Wilkinson
}

WENDY KEITNER

That LiteratURe, LIKe LANGUAGE, is not only a form of communication but also a repository of shared cultural assumptions is widely recognized and has been highlighted by feminist literary criticism. In poetry, woman's traditional role has been that of muse, who creates nothing directly, but, rather, puts herself at the service of another, as Simone de Beauvoir pointed out a generation ago in The Second Sex. Recent literary studies, including Elaine Showalter's $A$ Literature of Their Own, Susan Gubar and Sandra M. Gilbert's The Madwoman in the Attic and Shakespeare's Sisters, and Margaret Homans' Women Writers and Poetic Identity, probe the sources of woman's dislocation from the English language and the mainline, masculinist, literary traditions of Britain and the U.S. They begin to outline some of the reasons for the woman writer's surrender of the subjectivity and capacity for self-representation which are regarded as fundamental to poetic creativity. Although there has been relatively little discussion 
of these issues with respect to women writers in Canada, it is apparent that the convention of the poet as male, his speech Adamic, and the speaking voice of lyric poetry masculine has persisted right up to the contemporary period in Canadian literature as well.

The assumption that speech-naming the world-and poetry are masculine prerogatives is traced by Margaret Homans back through Emerson and Coleridge to Milton in Paradise Lost and, finally, to the creation myth in Genesis. The most significant restatement within the Canadian poetic tradition of the thesis which links the figure of Adam as the originator of language with that of the poet is undoubtedly Abraham Klein's celebrated "Portrait of the Poet as Landscape." Klein uses the masculine singular pronoun "he" for the figure of the artist, and he portrays the New World poet explicitly as "the nth Adam."1 Canadian women poets conformed to this convention, too, in the vast majority of their poems published between Isabella Valancy Crawford's Old Spookses' Pass, Malcolm's Katie, and Other Poems in I884 and Margaret Atwood's Double Persephone in 196I. In the current era, the identification of the poet with Adam has been challenged, and important questions are being raised by women writers: how does the consciousness of being a woman affect the workings of the poetic imagination? must a woman poet take part in self-definition only by contraries? how can "phallocentric" language create female poetic identity? who is the creative woman's muse? But, up until mid century, the most highly regarded Canadian women poets, like their British and American counterparts, typically strove to write like men, adapting their viewpoint-whatever the loss and distortion - to masculinist literary convention.

At the level of language itself, the normative use of masculine generic forms or the masculine pronoun can be disorienting, or, worse, can cause distortion of the truth about female activities. Classic examples are pronouncements such as "Man, like other mammals, breastfeeds his young," or "When we get abortion law repeal, everyone will be able to decide for himself whether or not to have an abortion." In poetry, too, "playing by the boys' rules" obscures the personal experiences of woman and distorts her speaking voice. $\mathrm{Nu}$ merous examples of denial, distortion, or self-contradiction on the part of the female poet-persona can be found in the poems published 
by women in Canada prior to mid century. The work of Audrey Alexandra Brown and of Anne Wilkinson, however, provides the clearest evidence of the distancing, splitting, or doubling.

Brown began her first book of poetry, A Dryad in Nanaimo (1931), with a conventional envoi entitled "The Poet to His Verse." This identification of the female poet as male epitomizes the central dilemma of the Western woman poet of this and earlier periods-from Sappho, through Lady Winchilsea, to Elizabeth Barrett Browning. The comment made by anthologists Barbara Segnitz and Carol Rainey in Psyche that "beginning with Sappho, the woman poet has provoked an uneasy response," 2 is apt and draws attention to the historic sense of a basic split, or even a contradiction in terms, between "woman" and "poet." Rejecting the second-class designation of "poetess," Brown, like Wilkinson, Webb, and scores of other Canadian women poets, simply projects herself as male. In her poems of the thirties and forties, whether she writes on the subject of nature, art, or even love, Brown utilizes a male persona and presents a conventional masculine viewpoint. While her verses lavish attention on male figures ranging from Christobal Colon to Robin Hood, presentations of women are almost totally absent; the few poems that do concern women are, nevertheless, narrated from a man's perspective.

For example, "The Passionate Poet" is about a male poet who longs to fashion "rare and beautiful things" for his loved one who is presented as delicate, childlike, and quintessentially "feminine," and to whom terms of endearment drawn from the subhuman animal and plant worlds ("my bird," "my flower") are applied. "The ImageMaker," on the subject of a male artist who carves a "girl" out of moonstone and, "Secure in her affections," adores her as the epitome of feminine passivity and compliance, again shows Brown's uncritical acceptance both of the stereotype of woman as faithless and of the artist as male. As long ago as Euripides, it was assumed that the accepted picture of woman as naturally evil might have been quite differently drawn if, from the beginning of time, the poet's lyre had been given to women as well as to men. But this insight, acknowledged in a rather wistful way by the Chorus in $M e d e a,{ }^{3}$ is not valid in the poetry produced by women so long as their goal was to write like men. 
Brown's most explicit rejection of the female point of view is given in her 194I speech to the Vancouver branch of the Canadian Authors' Association. Subsequently printed as Poetry and Life, this address consistently refers to the poet as "he," until, near the end, Brown specifically turns her attention to Canadian women writers. Revealing the extent to which she has distanced herself from the authenticity and value of her own womanhood, Brown chastizes her sister poets for an indulgence in a kind of poetry which, she says with obvious distaste, "I can only call typically spinster poetry," and which concerns itself with the subject of women's lost loves. Although Brown confesses she has occasionally succumbed to the lure of this topic herself, she charges that it is either untrue, and thus a "pathetic affectation," or else, if based on woman's personal experience, then "somewhat indelicate." She asks rhetorically, "What interest has the public, or ought the public to have, in our love-life?"4

Men, of course-Shakespeare and Donne, not to mention Irving Layton, among them-have always made poetry, which has been judged as "great" art, out of this realm of human experience, and they have frequently worked the conceit that human love is a reflection of the divine. But, as Virginia Woolf noted in $A$ Room of One's Own, literature has a correspondence to real life, and in both it has been the masculine viewpoint that confers value. "This is an insignificant book," critics judge, says Woolf," because "it deals with the feelings of women in a drawing-room."5 More recently, and referring to poetry in particular, feminist anthologist Suzanne Juhasz has elaborated on this discriminatory classification which has condemned many women and minority artists for being "limited" rather than "universal" in their appeal. Juhasz comments, "By not universal they mean, however, not including me, the man. The traditional criteria for poetry have described the poetry that men have made; it has been 'universal' because it has described the experience of MANkind."6 Until the middle of the twentieth century, the majority of our women poets internalized and indeed perpetuated this antifemale bias.

Illustrations abound, not only in the work of Audrey Alexandra Brown, but also in that of Anne Wilkinson. One of the most finely 
crafted and best known of Wilkinson's poems is "Lens," from her collection, The Hangman Ties the Holly (1955). The main subject of this poem is woman's submission to an aesthetic which equates the "manly" qualities of vigor, terseness, and supposed translucency with the essence of poetry itself. The opening stanza mentions four subjects that the poet is concerned about: "love and war/And wasps about the lilies/And mutiny within." The second stanza elaborates on the last of these, mutiny - the rebellion against lawful authority - which the female poet-persona struggles to suppress within herself. "Lens" focusses on the split between Wilkinson's personal identity as "woman" and her professional identity as "poet." "My woman's eye," she confesses, is "weak," "blind," and "veiled with milk." Contrasted to this is "The poet's eye," or "my working eye," which is described as "muscled" and as "crystal" clear, and which is identified as "my good lens." 7 The poem's title and central imagery are taken from photography; the poet longs to be a pellucid, "neutral" medium for the recording of "objective" realities and details of emotions. The tension between male and female opposites, or between personal and professional selves (reminiscent of the dualities which structure Elizabeth Barrett Browning's "Mother and Poet"), is resolved here, and typically in Wilkinson's writing, not by a blending of antithetical parts, but, rather, by the surrender of woman's individuality, Wilkinson's equation of masculinity with art eloquently and poignantly underscores the sexist bias of literary convention.

Discussion of Wilkinson's work by male critics has centered on its traditionalism, metaphysical wit, and "objectivity." Singling out "Lens" for special mention in his critical study, Commonwealth Literature (1973), William Walsh praises Wilkinson for manifesting the traditionally masculine traits of clarity, precision, and strength. $\mathrm{He}$ refers to Wilkinson's "pose" which is "perfect;" her "disinterestedness" which he calls "quite pure"; and the "clarity and the force, almost the ferocity, of the vision" so that "there is no sense of softness or accretion or pointless apposition." 8 What Walsh accords Wilkinson - and what, it must be acknowledged, Wilkinson, Brown, and, by and large, a half-century of Canadian women poets before them, strove to achieve for themselves, on account of the anti- 
narcissism that a male-dominated society induces in women - is validation as an honorary (female) man.

During the fifties and sixties, Canadian women poets such as Dorothy Livesay, P.K. Page, Jay Macpherson, Margaret Atwood, and Gwendolyn MacEwen began to reject the premise that "she" either could, or ought to be, made identical with "he." The antithetical and perhaps, finally, unassimilable nature of male and female experience of the world and their recreation in works of art, along with the subject of woman's submerged or "lost" identity, become increasingly important themes of the postwar and contemporary era. The inscription of the feminist "I," validation of "a way of looking that is distinctly from woman's eye, a way of feeling that is centred in woman's $I, " 9$ and an end to the contortions and distortions of widespread denial, splitting, or doubling, is an achievement, it is important to remember, that is not much more than a decade old.

Notes

${ }^{1}$ The Rocking Chair and Other Poems (Toronto, 1948), pp. 50-56. ${ }^{2}$ (New York, 1973), p. I5.

3"Medea," II. 4IO-30, trans. Rex Warner, in The Complete Greek Tragedies: Euripides I, ed. David Greene and Richard Lattimore (New York, 1967), p. 78.

${ }^{4}$ Privately printed by the Macmillans in Canada, p. 9.

5(1928; reprint Harmondsworth, Middlesex, 1975), p. 74.

${ }^{6}$ Naked and Fiery Forms. Modern American Poetry by Women: $A$ New Tradition (New York, 1976), p. 202.

7rpt. The Collected Poems of Anne Wilkinson, ed. A.J.M. Smith (Toronto, 1968), pp. 48-50.

${ }^{8}$ (London, 1973), p. 88.

9Dorothy Livesay, Foreword, Air, special issue "Woman's Eye," Nos. 19-2I (1974), p.v. 